Acta technologica agriculturae 3

Nitra, Slovaca Universitas Agriculturae Nitriae, 2013, p. 74-77

\title{
DEVIATIONS IN FUEL CONSUMPTION MEASUREMENT OF LORRIES
}

\author{
Mário SZABÓ, Radoslav MAJDAN, Michal ANGELOVIČ, Rastislav ČÁPORA \\ Slovak University of Agriculture in Nitra, Slovak Republic
}

\begin{abstract}
Our study focuses on individual methods of measuring the fuel consumption of lorries. We have verified the difference between the consumption calculated from fuelling records and consumption listed by the Infomax information system. Based on obtained results, we can state that the difference between presented consumption measurement methods reached the maximum value of $5 \%$.
\end{abstract}

Keywords: fuel consumption, Infomax, consumption measurement methods

The present-time competitive environment and high oil prices are reasons why all hauliers are seeking to reach cost savings. Driving fuel costs in transport companies create a significant part of expenditures. This is the reason why is it important to monitor the consumption of individual vehicles and to propose actions to reduce it in case of increased overconsumption.

A gradual development of motor vehicles increases the total efficiency of combustion engines, resulting in a reduction of specific fuel consumption (fuel consumption per unit of power). However, there is recently an increase in active, passive and ecological safety of newly manufactured motor vehicles (Lendák, 2008).

Besides economic reasons, reducing of fuel consumption is important even for ecological reasons. Vitázek (2006) points out that the utilization of primary energy sources affects the environment negatively during the extraction and processing of fuel, but especially during the transformation of one type of energy into another.

There are various methods for fuel consumption measurement, differing in accuracy and expensiveness. In presented tests, we will compare the average consumption listed by the Infomax system with the consumption calculated from the total amount of fuelling during the monitored period and travelled kilometres. More accurate information about consumption will be obtained by specially designed devices for a given type of vehicle, as indicated by Semetko et al. (1996), Janoško (1996), Janoško et al. (1996), and Žikla et al. (2010).

\section{Errors in consumption measurement}

A method based on measuring the fuel amount filled up into the main fuel tank during the monitored period uses the consumption calculation on the basis of kilometres travelled by the vehicle during the monitored period. Using this method is characterized by several errors. The technical condition of fuel dispensing pumps causes higher or lower differences between the displayed and actually filled-up fuel volume. We distinguish two types of fuel dispensing pumps:

- Fuel dispensing pumps at fuel stations are calibrated and periodically inspected. However, law allows a maximal permissible deviation of $\pm 0.5 \%$. Therefore, it allows a measurement of minimal deviations in advantage or disadvantage of customer;

- Private dispensing pumps are not subject to any official inspection, unless they are commercially used.

The temperature of fuel in the fuel tank is changing during the day. It is caused by changes of outside air temperature during the day as well as by returned un-injected fuel, which is heated by the engine, into the fuel tank. This change can have a dilatating and compensating effect. To ensure the measurement accuracy, it is important to constrain the effects of temperature changes and to keep the three basic conditions:

- The first condition is to eliminate the heating effect caused by returned fuel. It is important to fill the fuel up in cold conditions after vehicle stopping, when the temperature of the fuel tank is the same as outside air temperature;

- The second condition is to eliminate the effect of thermal changes between the fuel volume in the fuel tank and the fuel volume entering from the fuel reservoir. It is important to fill the fuel up when the fuel tank is practically empty;

- The last condition is to fill the fuel up at the same temperature. It is important to use a fuel reservoir stored underground.

Figure 1 presents the percentage of deviation in measurement when presented conditions are not met.

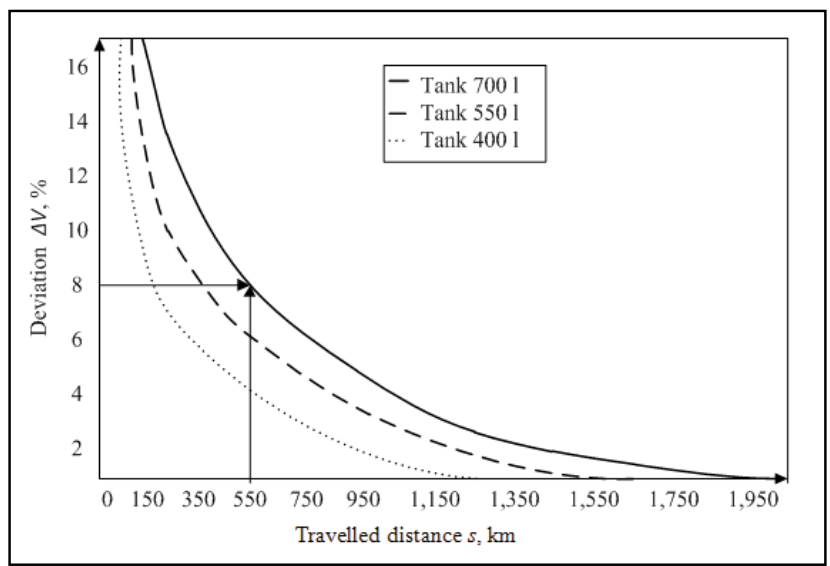

Figure 1 Evaluation of deviation in the procedure 'from full fuel tank into full fuel tank' Novotný, 2012 
Figure 1 shows the three basic fuel tank volumes according to travelled kilometres.

The presented figure (arrows) concerns a vehicle with an average fuel consumption of $35 \mathrm{l} / 100 \mathrm{~km}$, with a 700 litre fuel tank filled up to the maximum right after 500 travelled kilometres. The dilatability of fuel due to temperature effects leads to a deviation of $8 \%$ between the actually filled-up fuel and the fuel that could be filled up if fuelling is performed under cold conditions.

In fuelling, the procedure, from full fuel tank into full fuel tank' requires to reach in the fuel tank the same fuel level as that in a previous fuelling. It is important to ensure that the vehicle is on a flat foundation during fuelling and the level of filled-up fuel is always the same.

Some cases prove a sudden decrease of fuel in the fuel tank. This deviation could be caused by fuel theft. This could happen when the vehicle is stopped at rest, e.g. by means of a siphon system or by means of mechanical damage to the fuel tank. In this case, the value of measured fuel consumption will be higher than the actual.

The accuracy of consumption measurement based on used fuel and travelled kilometres is influenced by a deviation caused by a different energy value of fuel. It is possible to monitor differences in efficiency according to fuel producers and fuel origination. The engine control module $(E C M)$ is calibrated to a standard value; therefore, deviations are not taken into account.

\section{Errors in consumption measurement by means of Infomax on-board information system}

Input information for consumption measurement is saved in the vehicle, in a central control unit database. This information is available to the electronic system of the vehicle. For consumption calculation, the system uses information from the control unit and tachograph. The ECM provides information about the amount of injected fuel. The tachograph provides information about the travelled distance during the monitored period.

\section{Material and methods}

We have chosen the lorries of Zano-Trans, s.r.o. (private limited company) as our object of study. This company performs international and national road haulage up to $24 \mathrm{t}$.

The vehicle fleet consists of 25 RENAULT vehicles. There are 5 pieces of Renault Magnum and 20 pieces of Renault Premium Route. Tests were performed on 5 selected vehicles used for national road haulage.

We used two Renault Premium 460 vehicles with an engine power of $346 \mathrm{~kW}$ and three Renault Premium 420 vehicles with an engine power of $309 \mathrm{~kW}$. The vehicles were monitored in October 2011. To verify the consumption, we used information from the INFOMAX system as well as fuelling records of fuel and oils from October 2011.

We established few conditions to increase the objectivity of results, and these conditions were followed thereafter. Drivers always left the head office with a full fuel tank. After load transport, they always filled the fuel tank up to the full at the fuel station near the head office and returned to the garage with full fuel tank.

It was necessary to perform the information summarization, but fuelling records were available in a printed version. Therefore, we exported the information to the Microsoft Excel program. Drivers were required to record the amount of filled-up fuel and actual tachometer balance into fuelling records.

It was evident from fuelling records how many litres of fuel were filled up into the vehicle at the fuel station. Based on the tachometer balance as at the last day of previous month and tachometer balance as at the last day of actual month, we determined the travelled kilometres for the actual month. Consumption calculation was based on the following Eq. (1):

$$
S p=\frac{V}{S} \cdot 100
$$

where:

Sp - consumption, $\mathrm{l} / 100 \mathrm{~km}$

$V$ - amount of fuel used per month, I

$s \quad$ - travelled distance per month, $\mathrm{km}$

After the ride on the last day of the month, we downloaded the information using the INFOMAX software.

In the first phase, we chose the option Communication Data Downloading from the top toolbar of Infomax: Thereafter, we followed the instructions on the screen:

1. Verifying the extraction conditions:
a) the vehicle is stopped;
b) the engine is stopped;
c) the key in the ignition box is in the 'Contact' position.

2. Connecting the communication terminal into the USB port of PC (Power USB LED diode flashed up).

3. Connecting the communication terminal into the $O B D$ port of vehicle (Power Vehicle LED diode flashed up) (Figure 3).

4. Continuing by clicking on the 'Data Transfer' button.

The second phase was the information downloading itself. The system performed these operations automatically:

- Preparation of communication: performing the verification of active connection between the vehicle and Infomax system;
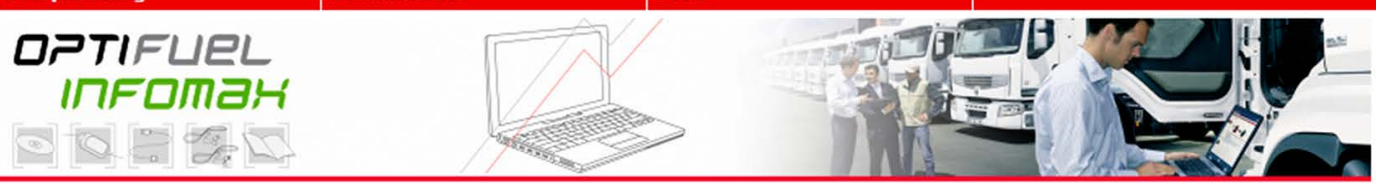

Figure 2

Process of data downloading in Infomax 


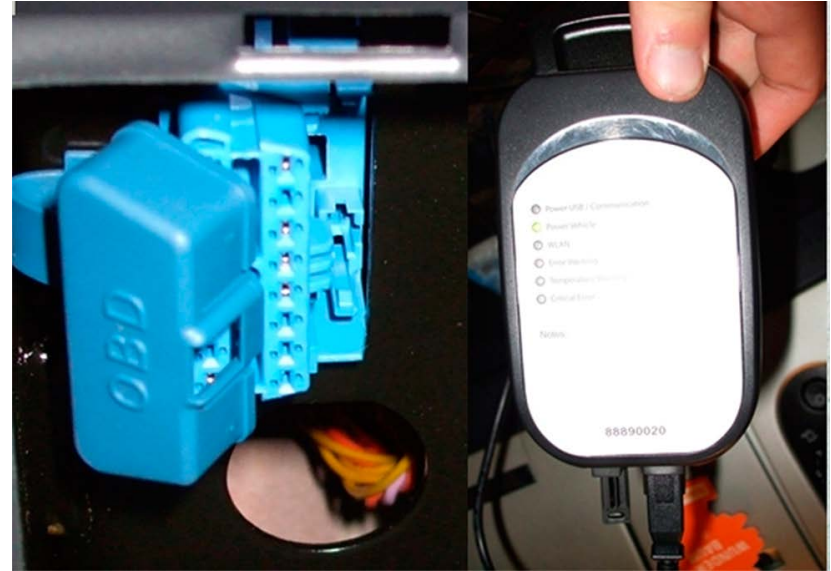

Figure 3 Connection of communication terminal into the OBD port

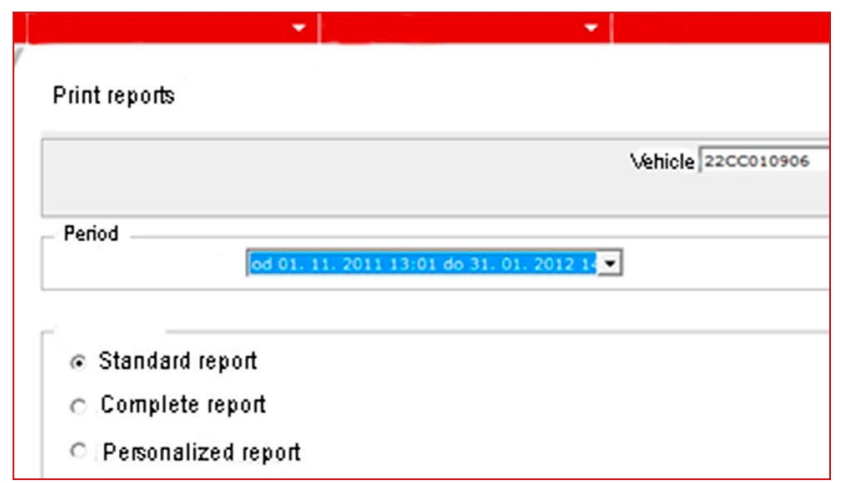

Figure 4 Printing of reports from Infomax

- Identification of vehicle: Infomax checked whether the connected vehicle is saved in the database. If not, its identification card was created automatically;

- Loading of information in the database: Infomax loaded all the information about the vehicle saved in the database;

- Saving of downloaded information: loaded information was saved as a copy in the connected PC.
After downloading of information, we started with data analysis. We needed a printed complete report about the vehicle to perform the most effective analysis. We chose the option Data Use - Report Printing from the top toolbar of Infomax.

On the displayed screen, we chose the vehicle as well as the time period for report generation. Three types of reports could be selected:

- Standard report to obtain a simple report with basic information only. We need one sheet of paper to print this type of report;

- Complete report containing all information available in the system. Information is organized into tables; graphs are situated at the end of the report;

- Personalized report allows printing information corresponding to specific needs.

After clicking on the, Report Generation' button, a report was displayed in Adobe Reader. From the generated report, we can obtain detailed information about the vehicle.

The program automatically calculates the travelled distance from the last data downloading, i.e. for the last month. This information is shown in the general report about the vehicle in the ,Distance per 1 ride' section. The program monitors the fuel used during engine operation, which is also shown in the general report. Based on this information, the program generates the vehicle consumption in $1 / 100$ $\mathrm{km}$. This information of fuel consumption during engine operation was compared with the consumption based on fuelling records.

\section{Results and discussion}

After data downloading, as presented in the previous chapter, we proceeded with results evaluation. Table 1 presents the travelled distance in kilometres, the amount of used fuel in litres measured by Infomax and the value calculated from fuelling records.

The difference between the consumption based on fuelling records and the consumption presented by Infomax is $5.56 \%$ in average.

Table 1 Consumption of individual vehicles in October 2011

\begin{tabular}{|c|c|c|c|c|c|}
\hline & Vehicle 1 & Vehicle 2 & Vehicle 3 & Vehicle 4 & Vehicle 5 \\
\hline \multicolumn{6}{|c|}{ Travelled distance $s$ in $\mathbf{k m}$} \\
\hline Infomax & 9,744 & 1,847 & 5,965 & 9,065 & 9,602 \\
\hline Fuelling record & 9,744 & 1,847 & 5,965 & 9,065 & 9,602 \\
\hline \multicolumn{6}{|c|}{ Filled-up fuel V in I } \\
\hline Infomax & 3,091 & 609.8 & 2,096 & 3,105 & 3,005 \\
\hline Fuelling record & 2,991 & 680 & 2,190 & 3,262 & 3,111 \\
\hline \multicolumn{6}{|c|}{ Consumption Sp in I/100 km } \\
\hline Infomax & 31.72 & 33.02 & 35.14 & 34.25 & 31.30 \\
\hline Fuelling record & 30.70 & 36.82 & 36.71 & 35.98 & 32.40 \\
\hline \multicolumn{6}{|c|}{ Difference } \\
\hline Used fuel $\Delta V$ in I & 100 & 70.2 & 94 & 157 & 106 \\
\hline Used fuel $\Delta S p$ in $\%$ & -3.24 & 11.5 & 4.49 & 5.06 & 3.51 \\
\hline
\end{tabular}




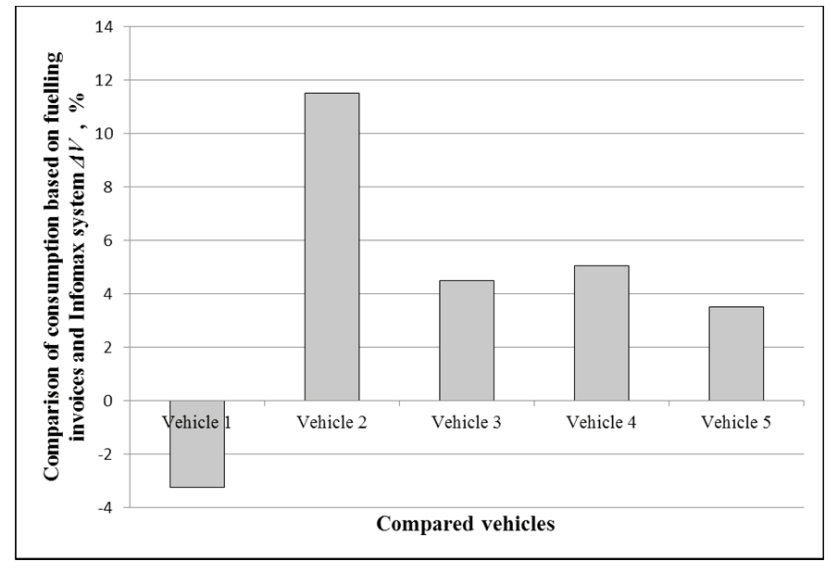

Figure 5 Comparison of consumption based on fuelling invoices and Infomax

If we present the results in a graphic form, it is obvious that the actually filled-up amount of fuel in vehicle 1 is lower than the fuel used during engine operation according to Infomax. This is unreal; therefore, we can assume that an error occurred during recording of information about the amount of filled-up litres into fuelling records.

\section{Conclusion}

As shown in Figure 5, the difference between the actual fuelling and actual consumption according to Infomax is $4.08 \%$ in average, if we do not take vehicle 2 into account, with an extreme deviation of $11.5 \%$.

This difference could be reduced if decilitres of fuel would be recorded into fuelling records, too.

Based on our results, we recommend Zano-Trans, s.r.o. to investigate reasons for the difference between the consumption based on fuelling records and Infomax in vehicle 2 . We recommended establishing a sanction system for drivers in case of a difference higher than $5 \%$ between the consumption based on fuelling records and Infomax because in these cases, there is a serious suspicion of fuel theft.

\section{Acknowledgement}

This study was prepared within the grant project of the Ministry of Education of the Slovak Republic VEGA 1/0857/12 ,Reduction of unfavourable impacts of agricultural and transport machinery on environment'.

\section{References}

JANOŠKO, I. 1996. Snímanie a monitorovanie spotreby paliva. In Zemědelská technika, vol. 42, 1996, no. 3, pp. 93-98.

JANOŠKO, J. - DRABANT, Š. - CALEK, M. 1996. Meranie spotreby paliva naftových motorov objemovou metódou. In Acta Technologica Agriculturae, vol. 37, 1996, pp. 37-43.

LENĎÁK, P. - JABLONICKÝ, J. - BOHÁT, M. - ŠVEC, J. 2008. Ekologická bezpečnost' motorových vozidiel v prevádzke. In VOZIDLÁ 2008. Nitra : SPU, s. 111-118. ISBN 978-80-552-0106-1.

NOVOTNÝ, J. 2012. Sprievodca spotrebou motorovej nafty [elektronická pošta]. Správa pre: Mário Szabó. 2012-03-06 [cit 2012-03-11]. Osobná komunikácia

SEMETKO, J. - JANOŠKO, I. - CALEK, M. 1996. Meranie spotreby paliva prietokomerom PLU $116 \mathrm{H}$. In Acta Technologica Agriculturae, vol. 37, 1996, pp. 27-33.

VITÁZEK, I. 2006. Tepelné procesy $v$ plynnom prostredí. Nitra : SPU. ISBN 80-8069-716-7.

ŽIKLA, A. - JABLONICKÝ, J. 2010. Reálny pohl'ad na spotrebu paliva. In Rol'nícke noviny, vol. 2010, 81, no. 14.

\section{Contact address:}

Ing. Mário Szabó, Slovak University of Agriculture in Nitra, Faculty of Engineering, Department of Transport and Handling, Tr. Andreja Hlinku 2, 94976 Nitra, Slovak Republic, e-mail: szabo@dtx.sk 